\title{
Men in the Remaking: Conversion Narratives and Born-Again Masculinity in Zambia
}

\author{
Adriaan S. van Klinken \\ SOAS, University of London \\ Thornhaugh Street-Russell Square, London WC1H 0XG, United Kingdom \\ a.van.klinken@soas.ac.uk
}

\begin{abstract}
The born-again discourse is a central characteristic of Pentecostal Christianity in Africa. In the study of African Christianities, this discourse and the way it (re)shapes people's moral, religious, and social identities has received much attention. However, hardly any attention has been paid to its effects on men as gendered beings. In the study of men and masculinities in Africa, on the other hand, neither religion in general nor born-again Christianity in particular are taken into account as relevant factors in the construction of masculinities. On the basis of a detailed analysis of interviews with men who are members of a Pentecostal church in Lusaka, Zambia, this article investigates how men's gender identities are reshaped by becoming and being born-again and how born-again conversion produces new forms of masculinity. The observed Pentecostal transformation of masculinity is interpreted in relation to men's social vulnerability, particularly in the context of the HIV epidemic in Zambia.
\end{abstract}

Keywords

men, masculinities, conversion, Pentecostalism, born-again Christianity, Zambia, HIV/AIDS

\section{Introduction}

'I am a man in the making.' This could be a quote from a female-to-male transgender person who undergoes a surgical procedure of sex reassignment; however, it is a quote from a young Zambian man identifying as a born-again Christian. He told me that after his conversion his understanding of manhood changed and consequently his self-understanding as a man as well. As he explained, he did not simply become a new man, but is striving to become a new man: he is a man in the making, or actually in the remaking. The accounts of other born-again men who were interviewed as part of this study reflect a similar pattern. Becoming born-again, attending a Pentecostal church, and 
living up to new moral and spiritual norms has put them in a process of gender transformation. In this process it is not their biological sex that is changed but their male gender identity. An analysis of the interviews in which these men share their stories, perceptions, and experiences provides insight into an issue that thus far has received little scholarly attention: the (re)construction of masculinity in African Pentecostal circles. This article offers such an analysis as a contribution both to the study of African masculinities and to the study of Pentecostal Christianity in Africa.

The study of men and masculinities in African contexts is an emerging field of study, as is demonstrated by the significant number of anthologies published on the subject in the last decade (Lindsay and Miescher 2003; Morrell 2001a; Mugambi and Allan 2010; Ouzgane and Morrell 2005; Shefer et al. 2007; Uchendu 2008). Some basic notions in this field of study are that masculinity is a category of gender applying to men, is a social construct, is not static but subject to change, and does not exist as a singular but as a plural (Morrell 2001b). Thus the concept of masculinities enables the investigation of male gender identities and of men's position in gender relations, both the relations among men and of men vis-à-vis women. Building on these insights and acknowledging that African (post)colonial societies have been and are experiencing deep social, cultural, political, economic, and religious changes, a central question in this field of study, in the words of Robert Morrell, is 'what forces operate to effect change in masculinities, when, where and how such changes occur, and what their effects are' (2001b, 7). In the scholarship on African masculinities little attention is paid to religion as a factor in the dynamic process of constructing, challenging, and transforming dominant forms of masculinity. This is strange - as I do not have to explain in this journal-because religion in Africa plays a vital role in many people's lives and in societies, and is an important factor in the construction of personhood and identity, including the gender identities of men and women in all their diversity and complexity.

In addition to the emergence of the study of masculinities in Africa, another obvious trend in academia is the interest in Pentecostal-Charismatic Christianity in Africa. This trend has been informed by the popularity of Pentecostal and Charismatic churches in Africa-as in other parts of the world-in recent decades (Kalu 2008; Meyer 2004; Robbins 2004). ${ }^{1}$ One of the characteristics of Pentecostal Christianity is its emphasis on the importance of a radical conversion, a transformative experience in which a person gives his or her life to Jesus Christ and becomes born-again. In Pentecostal discourse this event entails that the individual makes 'a complete break with the past' (Meyer 1998). It is often suggested that becoming born-again, more than a change in 
beliefs or doctrines, is above all about a change in lifestyle, a break with the immediate past of one's life and 'sinful' attitudes (Manglos 2010). In the words of Ruth Marshall, born-again conversion demands 'work of the self on the self' which 'through a variety of techniques... has as its effect a new sort of self-knowledge. That new self-knowledge has as its object protection, selfmastery, and spiritual empowerment, and it is explicitly linked to the creation of a certain type of life' $(2009,129)$. However, where the gendered aspects of born-again conversion and the subsequent new self-knowledge, spiritual empowerment, and new type of life have received attention as far as women are concerned (Frahm-Arp 2010; Mate 2002; Sackey 2006), these issues have barely been investigated with regard to men.

The two scholarly trends briefly outlined above-the emerging interest in African masculinities, and in Pentecostal Christianity in Africa-exist more or less independently from each other. The intersections of the two fields have hardly been explored. Little research is conducted on men and masculinity in African Pentecostalism. The small body of literature on the subject tends to focus on the official discourses on masculinity in Pentecostal circles (Chitando 2007; Soothill 2007; Van Klinken 2011) rather than on the narratives about, experiences with, and performances of masculinity among Pentecostal men. Birgit Meyer recently stated that 'much research is still needed on the consequences of becoming born again for people's personal and social identities, the relation with their partners, children and the wider family' $(2010 \mathrm{~b}, 121)$. One of the issues that needs to be explored is how becoming born-again affects men as gendered beings, and how it puts them into a process of transformation in which not only the moral and spiritual self but, related to that, the male self is also reshaped. From research in Zimbabwe, David Maxwell suggests that Pentecostalism 're-socialises the young man, drawing him away from a world of violence and promiscuity into a family-orientated life' (2006, 201). However, Maxwell does not substantiate this statement with empirical evidence. What does the resocialization or remaking of men look like in concrete lives and specific contexts, and how do men narrate and explain these changes themselves? These questions open up a new field of academic research in the study of Christianity in Africa. Research in this field is also crucial for non-academic reasons, given the current discussions on hegemonic forms of masculinity in Africa that are associated with violence, HIV/AIDS, and the oppression of women (Simpson 2009; Gibson and Hardon 2005). Against this background, non-governmental organizations today are 'targeting men for a change' (Bujra 2002), and several African theologians have embarked on a transformation of masculinities to produce new 'redemptive' and 'liberating' forms (Chitando and Chirongoma 2008; Phiri 2009). In this article I will not 
investigate how men in Pentecostal churches are subjected to a discursive transformation of masculinity, since I have done so elsewhere (Van Klinken 2011). Neither will I evaluate whether Pentecostal ideals of masculinity are 'liberating' and 'redemptive', as this requires a clearer (and normative) understanding of the meaning of these adjectives. Rather, I investigate how Pentecostal men themselves explain the changes in the self, especially in their perceptions of masculinity and their identities as men, that occur in the process of be(com)ing born-again.

\section{About This Study}

This article is based on in-depth interviews with seventeen men of various ages, but mostly in their twenties and thirties. They are all members of Northmead Assembly of God, a prominent Pentecostal church in Northmead, a suburb in Lusaka, the capital city of Zambia. This church is associated with the Pentecostal Assemblies of God in Zambia, a denomination that has its roots in the classical Pentecostal Assemblies of God movement in North America. The members of the church are relatively well educated and generally belong to the middle class of society. The majority are youths and young adults, of which quite a number are students.

The interviews were conducted in 2008 and 2009 when I was doing research in this church. The interviewees were selected more or less at random; I got to know these men when I attended church services and meetings of the church's ministries for youths, singles, married couples, and men respectively. In the selection of interviewees and in the analysis of the interviews, the factor of ethnicity was not taken into account. Although Zambia has many different ethnic groups, each with their own language and traditions, in postcolonial Zambia ethnicity is a factor of decreasing importance, especially in urban areas (Gewald, Hinfelaar, and Macola 2008). The post-independence politics of creating a 'Zambian' identity has been relatively successful, and Christianity is a key component of this identity, especially after the 1991 declaration by President Frederick Chiluba that Zambia is a Christian nation-a statement that is now enshrined in the preamble of the country's constitution (Gifford 1998). As anthropologist Elizabeth Colson puts it, the idea has grown that 'to be a Zambian means to be a Christian' $(2006,249)$. This idea is particularly strong among the growing group of Pentecostal and Charismatic Christians in Zambia (Cheyeka 2008). Indeed, the Pentecostal men that were interviewed for this study consider Christianity a fundamental part of their personal identity and rarely refer to their specific ethnic background. 
Many of the interviews can be read as conversion narratives. Men tell how they 'got saved', that is, the acceptance of Jesus Christ as their personal Saviour which is the first step in Pentecostal conversion, and how this changed their lives. Conversion narratives, as Henri Gooren points out, are not necessarily a factual description of the main events in one's life but are social constructions. An important element of these stories is what Gooren calls the biographical reconstruction: 'People who undergo a conversion experience literally reconstruct their lives, giving new meanings to old events and putting different emphases in the bigger "plot" of their life stories' (2010, 93). This anthropological notion informs my analysis of the interviews. The major questions that have guided my analysis are: (1) How do men narrate and describe the 'break with the past' in relation to their perception of themselves not just as born-again Christians but also as men? (2) In their view, what are the key characteristics of the ideal of born-again Christian manhood? (3) What challenges do they experience while trying to live up to this ideal, and how do they deal with these challenges? These three questions also structure this article.

\section{Pentecostal Men and the Break with the Past}

It is no surprise that Pentecostal men, while talking about themselves being a Christian and being a man, often come up with biographical stories about their conversion. These stories are largely variations of the typical formula of Evangelical and Pentecostal Christian conversion narratives all over the world: I was living in sin but now I'm saved. A good illustration is the following story, told by a young man in his early twenties whom I call Robert:

I am a Christian, meaning that I am born-again. I believe in Jesus Christ, and I do whatever a Christian is supposed to do. I got born-again some time back, in 2005. It was at the Copperbelt [the urbanised copper mining area in Zambia, AvK]. It was after I was involved in a kind of incident.... Before that I used to drink, I used to smoke, I was a bad boy, I was womanizing, had a lot of girlfriends. After a certain incident in my life, I decided that the life I was leading was not a good life. I just escaped from death. It was an attack, some people wanted to kill me after that I came from drinking in the night. Some people attacked me. After that I decided that it wasn't a good life. I thought, let me just give up alcohol and drugs and this kind of life, and become a Christian. From my upbringing I was a Christian, my family are Catholics, but I wasn't serious with that. It was only my parents, but I wasn't interested, I was just living my own life, saying: this is my life. But then I had that incident, and I decided to change. I just thought that the life I was living was dangerous. Even though I was in that bad life I used to hear about Christianity, the goodness of Christianity. So I thought, let me go back, let me go to Christianity. And above all, I will also enjoy the 
benefits of being a Christian, and one of them is having eternal life. Because when you believe in Christ you are going to have eternal life. But when you do not believe, and I was not believing by then, I would not experience eternal life. I thought: When I was killed, where would I have gone? I realized that I would have gone to hell. So I thought, let's give up this bad behaviour, this bad life. I knew some friends who were born-again Christians. What came into my mind was these friends of mine. So after thinking of getting born-again I approached those friends and said, guys, this is what is happening in my life. They used to know my life; they had been trying to evangelize me but by that time I was not interested. But now I came back to them and said, 'This is my time. I give my life to Jesus Christ'. And everything changed. My friends prayed for me and led me to the Lord and I accepted Jesus Christ.

The pre-conversion past in this story is described as the life of 'a bad boy', characterized by alcohol, drugs, girlfriends, and nightlife. This lifestyle is abruptly halted by a disastrous event, when Robert suffers a violent attack. The incident makes him realize that he is living a dangerous life. In retrospect, he considers his former life dangerous because of two reasons. First is the high susceptibility to violence and other dangers. Here Robert also points at the risk of HIV infection: 'My involvement with girls was very dangerous. In this time there is HIV and AIDS and a lot of diseases, but I wasn't careful. I could have contracted one of these diseases, but thank God I haven't'. Second, his life was dangerous because of the risk of going to hell and not inheriting eternal life. Generally, fear of dying and going to hell is an important motivation for converts. It has been suggested that men, out of gender stereotypes, rarely mention this fear in their conversion stories (Gooren 2010, 96). However, Robert had no problem in doing so, and neither did other men who also mention this aspect in their stories. Realizing that his life was dangerous and risky, Robert decided 'to go back' to Christianity. However, in spite of his nominal Catholic upbringing, he did not go back to the Catholic Church but to some born-again friends. Their earlier efforts to convert him turned out to be successful: Robert accepted Jesus Christ, gave his life to the Lord, and 'everything changed'. He is no longer 'a bad boy' but a committed born-again Christian who has broken with a sinful past.

It is evident that becoming born-again, in Robert's story but also in other stories, is far more about a change in moral lifestyle than a change in religious beliefs. The Pentecostal men in my study often marked a distinction between their past and new lives, and the difference concerns their way of life. Out of the four areas of 'deliverance' distinguished by Birgit Meyer (1998, 323-325) in Pentecostal discourse (deliverance from the immediate past, from the ancestral past, from occult bondage, and from demonic control and influence), their stories generally testify of 'deliverance from the immediate past', that is, their lifetime prior to becoming born-again. They have renounced sinful 
attitudes and made a new start. As Robert put it: 'God has forgiven me, because I confessed and repented at that time. And God is a God of a second chance; he has given me a second chance. I am in my second life'. Another interviewee captured the idea of experiencing a 'second life' and making a completely new start with a very evocative image. The young man, who claims that he had an active sexual lifestyle and is now actively involved in campaigns for HIV prevention through abstinence, stated: 'When being born-again, you start with an empty page. Justified in Christ. I am a secondary virgin'. The image of restored virginity is meaningful, first because it metaphorically illustrates the radical new start one makes after born-again conversion, and second, because it also illustrates the enormous concern in Pentecostal discourse with matters related to sex and sexual morality. From a gender perspective it is interesting to note that the preoccupation with virginity apparently has become gender blind; it no longer concerns only women but also men. The idea of a restored virginity implies, of course, that this virginity needs to be protected by following a strict moral code regarding sexuality. One's virginity cannot be restored for a second time, the self-named secondary virgin explained to me, which corresponds to the idea that one is born-again only once in a lifetime.

Some scholars indicate that becoming born-again for men can be a threat to their male identity. By giving up drinking, womanizing, and other activities that-according to the dominant norms of masculinity in their society-are considered 'manly', born-again men run the risk of being labelled as 'sissies' (Brereton 1991, 98-101; Gooren 2010, 103-105). Indeed, for Robert his conversion had direct consequences on his friendships: 'I lost some of my friends because I stopped drinking with them. I wanted to go back and join them, without drinking, but they felt uncomfortable with me, so they didn't want me. I was rejected by my former friends. I felt very bad'. Similar experiences of rejection and loss were recounted by other men. However, the question is whether renouncing 'manly activities' damages the masculine self-image of male converts, as Brereton suggests $(1991,99)$. From my analysis I observe a different tendency, to redefine the meaning of manhood so that born-again men can consider themselves even better men than they were prior to conversion, and better than their former peers. By breaking with the past and becoming born-again, their male identity is not damaged but rather reshaped and reaffirmed.

This is very evident in the following account of a man in his mid-twenties, whom I call Danny. Reflecting on the changes in his life after he became bornagain, Danny said: 
I used to stay on my own, to do my own things. I used to drink, to smoke, to have girlfriends, I used to mess around. I couldn't call myself a man because I wasn't responsible over my life and the life of others, and the feelings of others. But when I changed I became responsible and started to say: when I do this, my family is not happy, when I smoke I may get sick, this is not good for me. That is when I became a man because I started doing what God has purposed me to do.

The suggestion here is that real manhood is defined by responsibility. Being responsible over one's life and the lives of others- that is believed to be what God purposes a man to do. Therefore, in retrospect, in the period when Danny was 'playing around' and doing things that he and his friends at that time considered 'manly', he actually was not a man according to his new understanding. As he explained to me, 'After receiving Christ and after reading the word of God, now I think: being a man is being responsible, it is about accepting responsibilities. Being responsible over yourself, over your surrounding and for other people's life: for me, that is being a man'. Danny even gives a theological interpretation of this understanding of manhood by referring to God's command to Adam to keep the Garden (Gen. 2:15). In his opinion, the biblical creation story shows that 'a real man is supposed to be responsible, to take care for the environment'.

I later discuss in some detail the idea that manhood is about responsibility. Here my point is that for Danny and others this understanding comes as a result of being born-again. Getting born-again is not a disembodied spiritual rebirth but involves and affects men as gendered and embodied beings. Danny put this eloquently, saying: 'You have to accept Christ, and that is when God is going to make a man out of you'. Another interviewee referred to himself and his born-again friends as guys who have been 'remodelled' as men because God has taught them what is expected of a man. The respondents do not appear to be uncertain about their male identity since being born-again, though they are aware that others may consider them sissies. Rather, it appears that for these young adult men the break with the past entails a break with the norms of masculinity popular among their peers. Breaking with these norms seems to be a crucial step toward a stage of mature manhood, which in Zambia is generally associated with notions such as responsibility and wisdom and with roles such as being the head of the household and the provider for the family (Dover 2005). It could be argued, therefore, that becoming born-again is a new discursive rite de passage for young men in urban settings where traditional rites of passage and other ways of learning masculinity have largely disappeared. Looking back at his life prior to becoming born-again, one of the interviewees concluded, 'Being a Christian has really moulded me into a better man'. 


\section{The Ideal of Born-Again Manhood}

When manhood is redefined and male identity is reshaped among men as part of being born-again, the question is what new type of masculinity this brings about. What is the ideal of manhood that born-again men have constructed and live up to, possibly under the influence of the sermons and other teachings provided in their Pentecostal church?2 What, in their opinion, are the characteristics of being a born-again Christian man, and how do these relate to social and cultural notions and norms related to masculinity?

When talking about their lives as born-again Christians, several interviewees told me that they now live up to Christian moral values and that their lifestyle has thus changed. Recurring themes are that they stopped drinking, smoking, and having affairs, and that they have become more serious about life. These changes in behaviour and lifestyle are informed by religious ideals promoted in Pentecostal circles. For example, one respondent explained: 'Born again means you are following Christ, carrying the cross. Being a Christian man I have decided to follow Christ, I follow the values of Christ'. The motive of following Christ, imitatio Christi, is a classic Christian ideal much older than Pentecostalism; however, the example given by this interviewee directly illustrates the modern Pentecostal concern about sexual morality: 'Jesus taught about no sex before marriage; that is one of the values we actually follow through Christ'. Regardless of whether this assertion is correct-in the New Testament gospels Jesus does not say anything about sex before marriage- it is meaningful since it demonstrates how certain moral norms are directly attributed to Jesus Christ, who speaks with divine authority. In a similar way a church member explained to me that Christ prohibited the drinking of alcohol, completely ignoring that according to the Gospel of John Jesus changed water into wine. Another motive, mentioned by various interviewees, is the ideal of holiness, which is characteristic of Pentecostal Christianity and dates back to earlier Christian revivalist movements. Explaining this ideal, Robert, whose story was presented above, said:

To keep yourself holy means to live a life that is clean before God. Like for us guys no womanizing, no smoking, no drinking, no cheating, not doing things like this that are against God. Because God is holy, and the Bible says therefore we also have to be holy. Why it is important to be holy is that when you are holy you have that connection with God, that direct connection with God. I think that is the most important thing. God is holy, so when you are holy there is that direct connection with God.... To be holy, first of all you need to be born-again and to give complete your life to Christ and to be committed to the commands of God. 
Clearly, Robert considers holiness a condition for being connected to Godan idea that is derived from the Bible, Hebrew 12:14, which reads: 'Make every effort... to be holy; without holiness no one will see the Lord' (NIV). Robert refers to yet another biblical verse when he suggests that because God is holy 'we also have to be holy', a paraphrase of Leviticus 11:44. Other respondents also highlighted the ideal of holiness, but they referred to the notion of the body as a temple of the Holy Spirit (1 Corinthians 6:16-17). It is evident that these men follow the religious ideal of holiness so characteristic of Pentecostalism, motivating them to adhere to moral norms related to sexuality, relationships, and drinking.

It has been suggested that the process of sanctification in Pentecostal circles involves an element of surrendering that has a gendered dimension. On the basis of an analysis of women's conversion narratives, Virginia Brereton observes that 'entering into holiness or being sanctified meant letting God take over one's entire life, in all its dimensions... The sanctified woman was to give up to all effort and struggle and let God act in her life' $(1991,61,65)$. Further reflecting on Brereton's work, Gooren comments that 'women, because of their gendered socialization, would find it easier to yield, to surrender, to let go of control, than men' $(2010,107)$. If this is true, it is yet another aspect in which Pentecostal spirituality is problematic for men and a threat to their gender identity. However, my study reveals a more complex dynamic. On the one hand, interviewees made statements such as: 'You have to accept Christ, and that is when God is going to make a man out of you', suggesting that they give themselves over to God's transformative power. For these men this is also a bodily experience since during church services they actively participate in ecstatic worship and speak in tongues-two practices characteristic of Pentecostalism's 'sensational forms' through which people sense the presence of God and are amazed by Gods power (Meyer 2010a). The vulnerability mediated by and demonstrated in these bodily religious performances may make Pentecostal men 'un-manly' in the eyes of their peers. On the other hand, perhaps to compensate for their 'effeminate' spiritual corporeality, interviewees emphasized that holiness requires self-control. A recurring theme in their conversion stories is how they have learned to control their moral conduct. As one of them put it, "When you live through Christ, righteous living is a joy. Before that time it was the opposite, you like the promiscuous ways and all the lack of control. But now, there is control and righteous living is a joy'. This quote is typical of the emphasis on disciplining the self that is a commonly observed feature of Pentecostalism (Marshall 2009, 131; Martin 2002, 80). The practice of self-control appears to have a gendered dimension in the sense that it is central to the definition of born-again 
manhood. In contrast to their peers who cannot control themselves and simply follow their desires, for born-again men the ability to control the self becomes a way of proving male strength. The story of Danny, quoted above, is illustrative here. He states that he was not responsible for his life and in retrospect realizes he was not a man. Only after conversion, when he started to take responsibility for his life and to control his conduct, did he reach true manhood. 'That is when I became a man, because I started doing what God has purposed me to do.' Danny's story clearly shows how in the born-again program not only a new moral subject but a new male gendered subject is created, inspired by an alternative understanding of masculinity.

The link between self-control and born-again manhood is also drawn by the respondent quoted above, who claimed that Christianity moulded him into a better man:

Being a Christian has really moulded me into a better man. I know that there are certain attributes that you have to show as a Christian, behaviour that is expected of you, and some restrictions also.... Christian life goes with controls, and those controls help you in achieving certain things in life. When it comes to social life, for example nightlife that is something one can control. Without Christian teaching your life is reckless, you don't understand issues of sexuality and issues of managing your money, you easily spend your money. Thus living with these limitations makes you a better man.

Meetings of the men's ministry in the church provide opportunity for testimonies. Here men share how they have struggled and succeeded to control the self. These testimonies only reinforce the idea that self-control is a crucial aspect of born-again manhood. To put it in Foucauldian language, the witnessing of the efforts to control the self is an important 'technology of the self' among Pentecostal men through which born-again masculinity is constituted (cf. Marshall 2009, 152).

Self-control is not the only or the most central feature of born-again manhood. Pentecostal men have yet other ways to establish their male identity. Note, for example, that Danny in the above-quoted story tells that he, after being born-again, learned from the Bible that manhood is about taking responsibility. Making this concrete, he told me about his commitment to unite his family, which after the death of his parents had more or less fallen apart. Another respondent, a man in his thirties who is married and has a family, also emphasized that from a biblical perspective manhood is about responsibility. Being born-again, he said, reinforced his commitment to take care of his family materially and emotionally. Admitting that traditionally a man is supposed to look after his family, he yet stated: 'The Christian understanding 
puts it that the responsibility becomes more forward looking. It becomes a responsibility from God. Whereby if I don't do what I should do, it becomes an issue in my spirituality'. The emphasis on male responsibility does not mean that women, according to these interviewees, do not have responsibilities; however, they believe that men have a primary and fundamental responsibility. As one of them explained, 'I so much feel that God has put a higher premium, a higher demand on the man than on the woman. So the demand for men is higher, to really develop character.' This belief is informed by the creation story in Genesis 2. For these Pentecostal men, the fact that God created Adam first and gave him the responsibility of naming the animals and keeping the garden demonstrates the high expectations that God has of men in general. As one of them explained:

If you are a man, God expects a lot from you. When God made Adam, the Bible says:
God made a garden and put the man in it. Adam did not find a mansion, he did not
find a processing plant for juice. He found nothing, just a bush. He had to cultivate,
he had to work it, to take care of it. He had to start using his engineering mind, inno-
vation. For me that tells a lot about what God expects. God did not just tell: here
Adam, everything is finished, here you are. So that is what a man should do: start from
nothing, and do something. That is what every single man should do. He has to make
impact.

This theological argument can be considered to reflect the personal work discipline or the Protestant ethic with which Pentecostalism often is associated (Martin 2002, 10; Meyer 2010b, 112). However, it is even more interesting to note that this work ethic and discipline is part not of a general theological anthropology, but of a theological vision of masculinity. This vision motivates men to resist peer pressure, to challenge popular notions of masculinity in society, and to claim an alternative male identity.

Of course, in reality this refers to complex processes that are highly personal and depend on one's specific situation in life. Born-again masculinity is not a monolithic ideal but consists of some general notions, such as the idea of a God-given responsibility, that are applied to men's lives and are incorporated in men's gender identities in different ways. The following account provides some insight into such a personal process in which a born-again man redefined his identity as a man vis-à-vis social norms related to masculinity. It is the account of a single man, let's call him Bernard, in his mid-thirties:

Culturally a man has to be strong, has to marry, and so on. While marriage may not be there, I believe that one of the things a man should do is that he should make things happen, a man should accomplish things. Since I am not married and I am not 
perceived to be sexually active, I want to make sure that I am effective in what I do. Academically I want to make sure that I really do the best that I can. Ministry-wise I want to make sure that I am doing the best. These very things take away the seemingly sexual importance that people seem to perceive. If I am effective, I feel I am more of a man. When I am effective in ministry, that makes me a man. Because a man is supposed to provide leadership, and ministry is leadership. If you can influence people to attend meetings they are supposed to attend, and when you can teach people and they are getting saved and are growing in the things of God, that itself is potency. It makes you feeling that you are making a contribution. So I redefine it: being a man is not about being sexually active. What makes you a man is the fact that you are able to carry out a leadership role, either in the church or outside. It's not sexual features that make you a man, it is what you can do in your manliness rather than in your manhood, about being a man, being a leader, making things happen.

From his specific situation, being of an age by which a man is expected to be married, Bernard is not only faced with and struggling with the social expectation of marriage but - perhaps even more critically_also with popular ideas that equate masculinity with sexual performance. To avoid this association, he prefers to speak about manliness rather than about manhood. For him the term 'manliness' better captures the type of male character he has developed, which is defined by leadership, effectiveness, and influence. Concretely, this redefinition of masculinity means that Bernard pursues his academic studies and is committed to ministry in the church in addition to his professional responsibilities. He frankly admitted that he hopes to find a wife but, referring to the apostle Paul as an example, he also said: 'If you want to be effective you are better off as a single, especially when the calling you have is so huge'.

A final aspect of the ideal of born-again manhood reflected in the accounts of Pentecostal men in this study concerns their attitudes toward women. Because Pentecostal discourses on masculinity often emphasize notions such as male headship, male leadership, and a primary male responsibility, (pro)feminist scholars have often criticized Pentecostalism for reinforcing patriarchal constructions of masculinity and maintaining inequalities in gender relations (Chitando 2007; Nadar 2009). Indeed, Pentecostalism in Africa generally does not promote a modern (Western) notion of gender equality. Various respondents held views about gender relations that are easy targets for criticism from a feminist perspective. For example, one young man explained that

a man has to be the leader, the head of a relationship. You have eyes in the head, you have ears, a nose, a mouth. A man in the relationship has to have eyes, seeing where the relationship is going. He has to be creative. A man has to have ears, he has to hear and listen to his wife and to think. Then he has to talk and give direction. The wife is supposed to be the helper of the man. 
However, there are some interesting aspects in this man's account, who at that time was not in a relationship but was speaking about his future marriage. $\mathrm{He}$ suggests that a man has to listen to his wife before he makes decisions. In the interview he also told me that he is looking for a wife with whom he can share his ministry: 'Together we expect the Kingdom of God, together we can go to places all around the world to preach the Gospel.... I want our relationship to be focused on what God is telling us, the vision God has given us'. These comments of a young born-again Christian who dreams of a future serving God in global ministry are interesting because they indicate a significant level of partnership between husband and wife. Some married interviewees were more explicit about this. They provided concrete examples of partnership in their marriages, varying from helping their wife in the kitchen, to joint decision making, to encouraging their wife to pursue a professional career. Remarkably, they often emphasized that 'traditionally' this would not be possible, thus marking a distinction between Christian and African cultural configurations of gender relations in marriage. As one of them explained, after being born-again he had learned about the Christian understanding of marriage:

From the Christian point you find the basic foundational teaching: love your wife as Christ loves the church. You are taught to respect her and to commit only to her. It is not a master-slave relationship as it is traditionally, but it is about partnership.... The notion of the man as head is crucial, but unlike the traditional one it emphasizes a relationship where there is love and respect from both sides.

The comparison between the love of a husband for his wife and the love of Christ for the church is derived from the New Testament (Ephesians 5:23-25). Here, the apostle Paul qualifies the notion of male headship in marriage with a reference to Christ who is the head of the church and loves the church. According to various respondents, love and partnership are characteristic of a true Christian marriage but are largely absent in the traditional arrangement of marriage where male headship results in 'a master-slave relationship'. Such a representation, whether or not it is correct, confirms the observation that the break with the past that Pentecostalism advocates also includes a break with 'African culture' or 'African tradition' (Engelke 2004; Meyer 1998). The above account shows that this break is applied, among other things, to 'traditional' ideas about gender relations and masculinity.

The suggestion is that African culture is characterized by male dominance and oppression of women, while Christianity promotes love, partnership, and responsibility. Similar discourses have been found in Pentecostal circles in Ghana (Soothill 2007). Ezra Chitando has critically commented that 
Pentecostalism does not break radically enough with traditional African forms of patriarchy. He observes that Pentecostal definitions of masculinity are 'still rooted in the paradigm of the male as the leader' and uphold 'the myth of male headship' $(2007,122,124)$. This observation is correct, but it may overlook the transformations of masculinity taking place within these 'patriarchal' paradigms. The born-again men in my study bear witness to changes in their attitudes toward women, in marriage, and in broader gender relations. However, because these Pentecostal transformations of masculinity are wrapped up in a more or less patriarchal discourse, it can be difficult for (pro)feminist scholars to recognize and acknowledge them (Brusco 2010, 80; Van Klinken 2011).

\section{Dealing with Challenges and Resisting Temptations}

At first glance, conversion stories are often success stories. They tell how people got saved by accepting Jesus Christ as their personal saviour, and how their life has radically changed because they now live up to higher moral norms. On the basis of the narratives he studied, Gooren $(2010,106)$ observes that many Pentecostal converts described maintaining a new and far more disciplined lifestyle as an easy task. However, a closer look at the stories of born-again men in my study gives a different impression. The conversion itself may be constructed as a success story, but the process of sanctification that follows appears to be difficult and challenging. As Ruth Marshall put it, 'Becoming Born-Again is an event of rupture, but being Born-Again is an ongoing existential project, not a state acquired once and for all, a process that is never fully achieved and always runs of the risk of being compromised' (2009, 131). How, then, do men give an account of the challenging process of being born-again and living up to the ideal of born-again masculinity outlined above? What are the challenges they face, and how do they deal with these challenges?

One recurring theme is resistance from the outside, which is presented as a major challenge in life as a born-again Christian. Resistance can take different forms. Various men told me about confrontations with peers immediately after they became born-again, as in Robert's quote above. Another form of resistance comes from the family circle. Parents or relatives who are not Pentecostal Christians themselves may object to a son or brother who 'gives his life to Christ', especially when he starts to behave like a typical born-again Christian, including speaking in tongues and demonstrating an evangelisation drive. One respondent coming from a strong Catholic background explained that his born-again conversion was 'quite a big issue' for his family-so big 
that his father even threatened to exclude him from the family. Apart from the resistance from peers and relatives, men reported resistance throughout their Christian life, for example from fellow students at university or from colleagues in the workplace. To deal with these various forms of resistance it is believed that one has to be 'firm in Christ', as one interviewee put it: 'Jesus Christ really stood up for what he believed in, for what he considered to be the truth'.

Related to resistance from the outside are challenges in the category of being tested or tempted by others. This is illustrated by the story of one young man, whom I call Gift. In a meeting for single men taking place in the church there was time for testimonies, and Gift offered the following account about how he had recently lost his job:

\footnotetext{
When you are working as a single person, everybody is watching you. People want to try you, test you. My manager made advances to me. I loved my job so much. Some people are working there to please their bosses and they use them as toys, as sexual toys. But I wasn't going to do that. So I prayed about it. I talked about it with my mum. I went to a party with her [the manager], but I made up my mind not to end up sleeping with her..... It's a long story. At the end of the day, I loosed my job because I didn't want to enter into an affair with her. We should know our stand in Christ, we should not sleep with someone just because of money or to keep our job.
}

As in the previous stories about resistance from peers or family members, in this story the threat comes from the outside. However, in this story it is a woman who represents the threat of seduction. In a similar way, another respondent talks about challenges he sometimes faces in the office, such as when 'a woman [who] is showing out herself for me'. It appears that women and female sexuality are considered serious sources of danger to these bornagain men in their everyday lives.

Challenges from the outside such as those presented by women would not be so difficult to face if men were not also plagued by internal temptations. Most challenges reported by the Pentecostal men in this study fit precisely in the category of 'the weakness of the flesh'. These weaknesses are felt especially in the area of sexuality. Robert, for example, explained: 'We men mostly are weak.... It comes to women to be strong in this area. I don't know for others, but I am weak in this area, I am not strong'. Knowing his weaknesses, Robert has searched for a girlfriend with the same principles.

I am in a relationship right now, and I am surviving because my girlfriend is a believer. That protects me. We have been together for six months. Both of us are committed to the principle of no sex before marriage. We discussed it, and actually she is the one 
who is so serious about it. That is what makes me happy. You know, we as men are weak in this area, when it comes to intimacy. So I am happy to have a girlfriend who is principled.

In this account self-control, identified above as a characteristic of born-again manhood, seems to be left to the female partner. Yet Robert himself claims to respect limits, referring to his conscious decision after becoming born-again to avoid girls and only enter into a relationship with a girl who shares his principles. It is noteworthy that in the above quote he uses the word 'surviving'. Apparently abstaining from sex is an issue of survival for him as a Christian man. Like Robert, other men generally indicated to support the moral principle of abstaining from sex before and outside marriage, yet some respondents suggested that they negotiate the strict moral norms taught in the church. A young man who is engaged openly described kissing as a 'delicate issue' he struggles with:

Even though I am in the Christian life right now, it doesn't mean that I don't have challenges. For example, issues such as kissing or no kissing. It's a very delicate one. It is an issue for all of the youth. From the pulpit it is told: 'Don't do it, because one thing leads to another'. But we do it, the majority of the guys do it. And we end up feeling sorry about it because they say: 'Don't do it'. It's a constant struggle. Good and evil. You can't constantly regulate yourself. I feel like Spider Man. It is a delicate balance. You want to do it, and the next day you don't want to do it. I do it, but that is as far as it goes.

This quote illustrates some of the complex processes of negotiation taking place in the born-again male self. It shows that for born-again men, to live up to the Pentecostal ideal of manhood and its related moral norms results in a constant struggle with their fleshy desires. They may give in to the desire of kissing, but 'that is as far as it goes', meaning that they continue to struggle with other desires. Even though they realize that it is difficult, if not impossible, to constantly regulate the self, they can already feel guilty after giving in to a desire to kiss their fiancé.

For born-again men, facing challenges and temptations, both internal and external, appears to be part of life. They are not simply on a one-way trajectory of conversion and sanctification but are involved in a constant negotiation, trying to maintain the 'delicate balance' between moral and spiritual norms and the ambiguities and difficulties of their daily lives (cf. Coleman 2011, 243-244). It is precisely in these processes of negotiation that aspects of identity and agency become visible. Agency can be seen in the ways and means with which born-again men resist the temptations they face while trying to 
live up to Pentecostal ideals of masculinity and morality. Self-control is an important component of individual agency in this context. The following quote from Bernard, the single man cited above, gives some insight into how self-control works to resist temptations in the area of sexuality:

\begin{abstract}
The sexual feelings and passions are always there, but what I have come to learn over the years is that these feelings can be channelled into other things. When I feel the pressure of being attracted to somebody, of course I would not go ahead and aspire the cravings of my flesh, but I would pray and I would use these energies elsewhere. For me, these passions come as an accumulation of energy, and I always channel that energy into other things. And eventually when I channel them like that, they drive off. But it's a struggle that continues, it is one area where you pray: God, give me the grace to conquer this. And one day in time you will be winning this battle and the next battle and so on. It is a continuous battle field, but it can be handled. You handle it through prayer and also by taking time out, concentrating on other things. You go out to meditate, just being with God and thinking about the things of God.
\end{abstract}

Studies and Christian ministry rather than sexual activity are crucial for Bernard to achieve 'manliness', that is to shape his male identity. Spiritual practices such as prayer and meditation are mentioned as important means in the constant struggle with temptations. Prayer especially is mentioned by other respondents. One said that every day when he leaves his house, he prays a preventive prayer: 'Help me clean my temple, not to do wrong, something that will be so disgusting in your sight'. The reference to prayer as a spiritual means of resisting temptations suggests that God is believed to be involved in the struggle of born-again life. Indeed, one respondent observed that when he feels temptations, he hears an internal voice saying: 'This is a sin, don't do it'. He feels that this is the voice of God warning him. 'In that way God helps me. Whenever I want to do something bad, there is that voice, like a reminder'. However, in his opinion the warning presence of God does not diminish his individual responsibility and accountability: 'There is that voice, but I have to decide whether I listen to the voice or not'. In addition to warnings, God also helps when one is faced with temptations. Several respondents stated, for example, that 'God gives you the ability to have self-control', that 'the Holy Spirit protects you from certain things', and that 'God will be helping you, encouraging you, and gives you the strength to stand firm'. Remarkably, the born-again men in this study do not so much speak about miraculous interventions of God in their lives (cf. Marshall 2009, 155); their stories rather suggest that God is actively present, but in the background of their lives. God warns them, encourages them and gives them strength, but moral transformation is first and foremost a task of the reborn self. However, because this process of transformation or sanctification is full of challenges and temptations, 
men realize that they cannot do it themselves alone. 'Being a born-again man', as one respondent put it, 'is not something that you achieve on your own. It has to take God.... I can't say: I am arrived. I have my mistakes. I am still a man in the making.'

\section{Born-Again Masculinity, Social Vulnerability, and AIDS}

As mentioned in the introduction, a key question in the study of African masculinities is 'what forces operate to effect change in masculinities, when, where and how such changes occur, and what their effects are' (Morrell 2001b, 7). This case study suggests that Pentecostalism is a major force operating to effect change in men and masculinities. The question arises as to how the apparent Pentecostal success in transforming masculinities can be understood. What is the socio-cultural background against which we can explain and understand the changes to which the born-again men in this study have testified?

Frederick Klaits (2011) recently pointed to the theme of ongoing vulnerability to suffering 'as an existential condition within the diverse Christian movements in Africa', and as key to understanding how the self is experienced and transformed among African Christians. In contemporary African contexts this vulnerability can relate to many social, cultural, and spiritual realities people face. In a broader study on men and masculinities in African Pentecostal circles, it would be interesting to look at the theme of male disempowerment (Silberschmidt 2005). This theme refers to men who, due to socio-economic changes and impoverishment, are no longer able to live up to the expectations and roles that they are supposed to fulfil according to society. It would be interesting to see how Pentecostal conversion enables these men to regain their dignity and self-worth. However, this theme is not so relevant in view of the men participating in the present study since they are not so much disempowered socio-economically; generally they are employed and belong to the middle class of society. Far more relevant here is men's vulnerability in the context of the HIV epidemic. The interviewees, just like other men in Zambia and elsewhere in Africa, are living in the shadow of AIDS. As Anthony Simpson points out, 'What is perhaps less self-evident in view of the real power exercised by many men in everyday life in Zambia and elsewhere is the vulnerability of men because of the demands made upon them by particular constructions of masculinity' $(2009,5)$. In his study Simpson reveals some of the hegemonic norms of masculinity in Zambia, such as the idea that real men are superior to women, have to exhibit strength - at times in verbal and physical violence against women, and have to prove their virility and demonstrate sexual potency. These norms lead to sexual behaviour that is particularly dangerous 
in times of HIV and AIDS. The born-again men in this study are fully aware of this danger. Many of them had relatives and friends who died of AIDS. Out of these experiences they have come to realize, as one respondent put it, that 'a few minutes of passion can mean death, can ruin your dreams'. This quote clearly shows that men are aware of their vulnerability to the disease. They realize that in their lives prior to becoming born-again they could easily have been infected with the virus, and they thank God that He protected them. Referring to their former peers for whom masculinity is tied up with sexual performance, they emphasize that true manhood is characterized by self-control. It seems that Pentecostal Christianity, in particular its born-again discourse, provides these men with a way of coping with the vulnerability sensed in the shadow of HIV/AIDS. Like other religious groups and secular prevention messages, Pentecostalism promotes sexual abstinence before and fidelity in marriage as key measures in preventing the spread of HIV. However, Pentecostalism does not simply emphasize these moral norms; its born-again program is a discursive regime through which men can indeed make a break with the past, including dangerous forms of masculinity, and-empowered by God-become new male selves that no longer live lives that make them vulnerable to the dangers of HIV and AIDS.

\section{Conclusion}

This article suggests that in contemporary Africa Pentecostal Christianity is a discursive regime that produces new forms of masculinity and brings about change in men's gender identities. I use the word 'suggest' because this article is based on a relatively small amount of data, and because the men interviewed are all members of one Pentecostal church in Lusaka, Zambia. This sample is too small to draw general conclusions on the (re)construction of masculinities in Pentecostal circles in Africa. However, for the Zambian Pentecostal men participating in this study becoming born-again and living as born-again Christians has an enormous impact, not only on their religious but also on their gender identities. Clearly, for them the break with the past advocated by Pentecostal Christianity entails a break with popular forms of masculinity in society that they associate with drinking, sexual aggressiveness, violence, absence from the family, and the oppression of women. Among other things, becoming born again means that they adopt a new understanding of manhood. In their opinion, this new concept of masculinity is biblical and Christian and therefore is a break with popular and traditional understandings. For them being born again, in traditional Pentecostal terms the phase of sanctification, 
is the phase of living up to and negotiating their new understanding of manhood and related moral norms while struggling with various challenges and temptations. The accounts of these Pentecostal men suggest that within the discursive frame of born-again Christianity their male gender identity is reshaped and a new, more mature type of masculinity is constructed.

One could ask what is 'African' about the picture of born-again masculinity outlined above, except that it emerges from the narratives of Zambian men. Indeed, Pentecostal men in other parts of the world could provide similar stories since Pentecostalism is a global religious discourse. However, it is important to see that the men in this study construct a Christian identity that is in contrast to an African identity. Note, for example, how they associate male oppression of women and violence against women with 'African culture' and how they oppose this to Christianity, which in their opinion encourages men to respect women and to strive for partnership in marriage. This exemplifies the negotiation of identity that is characteristic of men and masculinities in African Christianities. In the Pentecostal trajectory born-again masculinity is defined as a break with 'tradition' and 'African culture' since these are considered responsible for the moral and social crises in African societies. As represented by the men participating in this study, born-again masculinity has a more 'modern' appearance, shaped by a globalising American evangelical discourse of 'biblical manhood' (Van Klinken forthcoming). The Pentecostal gender paradox, a concept coined by Bernice Martin (2001), is clearly manifested in born-again masculinity, such as when the men in this study embrace the notion of male headship on the one hand, while on the other hand emphasize respect, partnership, and even equality in gender relations.

Although the amount of data is too small to draw general conclusions, it is reasonable to argue that the findings of this study reveal a broader trend in Pentecostal Christianity in Africa. The men involved in the present study are members of a church with an explicit discourse on masculinity: an ideal of 'biblical manhood' is preached from the pulpit and the church's men's ministry aims to help men striving toward this ideal (Van Klinken forthcoming). This example of church-based masculinity politics is not unique; similar discourses have been found in Pentecostal circles in other African Countries (Chitando 2007; Soothill 2007). Concerned as it is with 'rebuilding the individual' through moral and spiritual renewal (Kalu 2008, 213-215), African Pentecostalism seems to specifically target men for a change. Pentecostalism is apparently responding to the 'crisis of masculinity' in contemporary African societies, revealed by the HIV epidemic and other social and cultural dynamics (Hunter 2010; Simpson 2009; Uchendu 2010). This article shows how typical Pentecostal notions such as becoming born-again, the break with the 
past, and the ideal of holiness and sanctification together create a frame in which men's lives can change and men's identities as men can be reshaped. A central notion in masculinity theory is that men are always in the (re)making because masculinity is not a stable and static construct. Therefore it is not surprising to find changes in male gender identities among born-again men in a Zambian Pentecostal church. However, it is fascinating that these men are explicitly aware of being men in the (re-)making and that they clearly testify to changes in their lives and identities as a result of being born-again.

\section{Acknowledgements}

The author would like to thank those who were interviewed as part of the project and who were willing to share their experiences and stories. Many thanks also go to the anonymous reviewers of this journal for their helpful comments on the article, and to Ellie Higgs, a $\mathrm{PhD}$ candidate in the Centre for Gender and Religions Research at SOAS, for proofreading and commenting on this article.

The author gratefully acknowledges the support of the Netherlands Organisation for Scientific Research (NWO Rubicon postdoctoral fellowship, no. 446-11-006).

\section{References}

Brereton, Virginia L. 1991. From Sin to Salvation: Stories of Women's Conversions, from 1800 to the Present. Bloomington: Indiana University Press.

Brusco, Elisabeth. 2010. 'Gender and Power'. In A.H. Anderson, M. Bergunder, A. Droogers, and C. van der Laan (eds.), Studying Global Pentecostalism: Theories and Methods. Berkeley, Los Angeles, and London: University of California Press, 74-92.

Bujra, Janet. 2002. 'Targeting Men for a Change: AIDS Discourse and Activism in Africa'. In F. Cleaver (ed.), Masculinities Matter! Men, Gender and Development. London and New York: Zed Books, 209-234.

Cheyeka, Austin M., 2008. 'Towards a History of the Charismatic Churches in Post-Colonial Zambia'. In J.B. Gewald, M. Hinfelaar, and G. Macola (eds.), One Zambia, Many Histories: Towards a History of Post-Colonial Zambia. Leiden: Brill, 144-163.

Chitando, Ezra. 2007. 'A New Man for a New Era? Zimbabwean Pentecostalism, Masculinities and the HIV Epidemic'. Missionalia 35.3, 112-127.

Chitando, Ezra and Sophie Chirongoma. 2008. 'Challenging Masculinities: Religious Studies, Men and HIV in Africa'. Journal of Constructive Theology 14.1, 55-69.

Coleman, Simon. 2011. 'Introduction: Negotiating Personhood in African Christianities'. Journal of Religion in Africa 41.3, 243-255.

Colson, Elisabeth. 2006. Tonga Religious Life in the Twentieth Century. Lusaka: Bookworld. 
Dover, Paul. 2005. 'Gender and Embodiment: Expectations of Manliness in a Zambian Village'. In L. Ouzgane and R. Morrell (eds.), African Masculinities: Men in Africa from the Late Nineteenth Century to the Present. New York: Palgrave Macmillan, 173-188.

Engelke, Matthew. 2004. 'Discontinuity and the Discourse of Conversion'. Journal of Religion in Africa 34.1-2, 82-109.

Frahm-Arp, Maria. 2010. Professional Women in South African Pentecostal Charismatic Churches. Leiden: Brill (Studies of Religion in Africa, 38).

Gewald, Jan-Bart, Marja Hinfelaar, and Giacoma Macola. 2008. 'Introduction'. In J.B. Gewald, M. Hinfelaar, and G. Macola (eds.), One Zambia, Many Histories: Towards a History of Post-Colonial Zambia. Leiden: Brill, 1-13.

Gibson, Diana and Anita Hardon (eds.). 2005. Rethinking Masculinities, Violence and AIDS. Amsterdam: Het Spinhuis.

Gifford, Paul. 1998. 'Chiluba’s Christian Nation: Christianity as a Factor in Zambian Politics 1991-1996'. Journal of Contemporary Religion 13.3, 363-381.

Gooren, Henri. 2010. 'Conversion Narratives'. In A.H. Anderson, M. Bergunder, A. Droogers, and C. van der Laan (eds.), Studying Global Pentecostalism: Theories and Methods. Berkeley, Los Angeles, and London: University of California Press, 93-112.

Hunter, Mark. 2010. Love in the Time of AIDS: Inequality, Gender, and Rights in South Africa. Bloomington: Indiana University Press.

Kalu, Ogbu U. 2008. African Pentecostalism: An Introduction. New York and Oxford: Oxford University Press.

Klaits, Frederick. 2011. 'Introduction: Self, Other and God in African Christianities'. Journal of Religion in Africa 41.2, 143-153.

Kollman, Paul. 2010. 'Classifying African Christianities: Past, Present, and Future: Part One'. Journal of Religion in Africa 40.1, 3-32.

Lindsay, Linda A. and Stephan Miescher (eds.). 2003. Men and Masculinities in Modern Africa. Portsmouth, NH: Heinemann.

Manglos, Nicolette D. 2010. 'Born Again in Balaka: Pentecostal versus Catholic Narratives of Religious Transformation in Rural Malawi'. Sociology of Religion 71.4, 409-431.

Marshall, Ruth. 2009. Political Spiritualities: The Pentecostal Revolution in Nigeria. Chicago, IL and London: University of Chicago Press.

Martin, Bernice. 2001. 'The Pentecostal Gender Paradox: A Cautionary Tale for the Sociology of Religion'. In R.K. Fenn (ed.), The Blackwell Companion to the Sociology of Religion. Malden: Blackwell, 52-66.

Martin, David. 2002. Pentecostalism: The World their Parish. Malden, Oxford, and Carlton: Blackwell Publishing.

Mate, Rekopantswe. 2002. 'Women as God's Laboratories: Pentecostal Discourses of Femininity in Zimbabwe'. Africa 72.4, 549-568.

Maxwell, David. 2006. African Gifts of the Spirit: Pentecostalism \& the Rise of a Zimbabwean Transnational Religious Movement. Oxford, Harare, and Athens, OH: James Currey, Weaver Press, and Ohio University Press.

Meyer, Birgit. 2010a. 'Aesthetics of Persuasion: Global Christianity and Pentecostalism's Sensational Forms'. The South Atlantic Quarterly 109.4, 741-764.

. 2010b. 'Pentecostalism and Globalization'. In A.H. Anderson, M. Bergunder, A. Droogers, and C. van der Laan (eds.), Studying Global Pentecostalism: Theories and Methods. Berkeley, Los Angeles, and London: University of California Press, 113-130. 
2004. 'Christianity in Africa: From African Independent to PentecostalCharismatic Churches'. Annual Review of Anthropology 33, 447-474.

. 1998. "Make a Complete Break with the Past": Memory and Post-Colonial Modernity in Ghanaian Pentecostalist Discourse'. Journal of Religion in Africa 28.3, 316-349.

Morrell, Robert (ed.). 2001a. Changing Men in Southern Africa. Pietermaritzburg and London: University of Natal Press and Zed Books.

2001b. 'The Times of Change: Men and Masculinity in South Africa'. In R. Morrell (ed.), Changing Men in Southern Africa. Pietermaritzburg and London: University of Natal Press and Zed Books Ltd, 3-37.

Mugambi, Helen N. and Tuzyline J. Allan (eds.). 2010. Masculinities in African Literary and Cultural Texts. Banbury: Ayebia Clarke Publishing Ltd.

Nadar, Sarojini. 2009. “"The Bible Says!” Feminism, Hermeneutics and Neo-Pentecostal Challenges'. Journal of Theology for Southern Africa 134, 131-146.

Ouzgane, Lahoucine and Robert Morrell (eds.). 2005. African Masculinities: Men in Africa from the Late Nineteenth Century to the Present. New York: Palgrave Macmillan.

Phiri, Isabel A. 2009. 'Major Challenges for African Women Theologians in Theological Education (1989-2008)'. International Review of Mission 98.1, 105-119.

Robbins, Joel. 2004. 'The Globalization of Pentecostal and Charismatic Christianity'. Annual Review of Anthropology 33, 117-143.

Sackey, Brigid M. (2006). New Directions in Gender And Religion: The Changing Status of Women in African Independent Churches. Lanham: Lexington Books.

Shefer, Tamara, Kopano Ratele, Anna Strebel, Nokuthla Shabalala, and Rosemarie Buikema (eds.). 2007. From Boys to Men: Social Constructions of Masculinity in Contemporary Society. Lansdowne: UCT Press.

Silberschmidt, Margarethe. 2005. 'Poverty, Male Disempowerment, and Male Sexuality: Rethinking Men and Masculinities in Rural and Urban East Africa'. In L. Ouzgane and R. Morrell (eds.), African Masculinities: Men in Africa from the Late Nineteenth Century to the Present. New York: Palgrave Macmillan, 189-204.

Simpson, Anthony. 2009. Boys and Men in the Shadow of AIDS: Masculinities and HIV Risk in Zambia. New York: Palgrave Macmillan.

Soothill, Jane E. 2007. Gender, Social Change and Spiritual Power: Charismatic Christianity in Ghana. Leiden: Brill (Studies of Religion in Africa, vol. 30).

Uchendu, Egodi (ed.). 2008. Masculinities in Contemporary Africa. Dakar: Codesria.

Van Klinken, Adriaan S. 2011. 'Male Headship as Male Agency: An Alternative Understanding of a Patriarchal African Pentecostal Discourse on Masculinity'. Religion and Gender 1.1, 103-124. http://www.religionandgender.org/index.php/rg/article/view/ $19 / 22$.

- Forthcoming. Transforming Masculinities in African Christianity: Gender Controversies in Times of AIDS. Aldershot: Ashgate Publishing.

\section{Notes}

1. The broad term 'Pentecostal-Charismatic Christianity' refers to a variety of Pentecostal and neo-Pentecostal or Charismatic Christian traditions in Africa with different historical roots and social and theological characteristics (see Kollman 2010; Meyer 2004). In this 
article I simply refer to Pentecostalism since my case study was conducted in a congregation of the Pentecostal Assemblies of God in Zambia, a denomination that can be better classified as Pentecostal than as neo-Pentecostal/Charismatic.

2. In this church, Northmead Assembly of God, I found a rather explicit discourse on masculinity. For example, in 2008 a series of sermons was preached on the theme 'Fatherhood in the 21 st Century'. In these sermons the preacher criticized the 'distortion of manhood' he observed in society and promoted an alternative ideal of 'biblical manhood'. I analyze these sermons and the broader discourse on men and masculinity in this church in my forthcoming monograph. 